\title{
Cell per Flask
}

National Cancer Institute

\section{Source}

National Cancer Institute. Cell per Flask. NCI Thesaurus. Code C73638.

A unit of cell concentration expressed as a number of cells per flask. 